\title{
Chemical Constituents and Cytotoxic Activities of Essential Oils from the Flowers, Leaves and Stems of Zingiber striolatum Diels Minyi Tian ${ }^{1}$, Yi Hong ${ }^{1}$, Xianghuan Wu ${ }^{1}$, Min Zhang ${ }^{1}$, Bing Lin $\odot^{1,2^{*}}$ and Ying Zho $\odot^{1,2^{*}}$
}

${ }^{1}$ Guizhou Engineering Center for Innovative Traditional Chinese Medicine and Ethnic Medicine, Guizhou University, Guiyang 550025, P. R. China

${ }^{2}$ College of pharmacy, Guizhou University of Traditional Chinese Medicine, Guiyang 550025, P. R. China

(Received May 22, 2019; Revised July 02, 2019; Accepted July 05, 2019)

\begin{abstract}
The purpose of this study was to investigate chemical composition and cytotoxic activities of essential oils from Zingiber striolatum Diels flowers, leaves and stems. 73, 68 and 66 compounds representing 97.0\%, $94.8 \%$ and $93.7 \%$ of flowers, leaves and stems essential oils were identified using GC-FID and GC-MS, respectively. The main constituents of the flowers oil were $\beta$-phellandrene $(28.5 \%), \alpha$-humulene $(14.7 \%), \beta$-pinene $(8.2 \%), \beta$-elemene $(5.5 \%)$, humulene oxide II $(3.5 \%)$, cryptone $(3.3 \%)$ and tricosane $(3.2 \%)$. The predominant components in the leaves oil were hexahydrofarnesyl acetone $(24.7 \%), \alpha$-humulene (12.2\%), phytol (11.9\%), humulene oxide II $(6.3 \%), \beta$-pinene $(4.3 \%)$, sandaracopimaradiene $(3.1 \%)$ and $\beta$-elemene $(3.0 \%)$. The stems oil contained mainly $\alpha$-humulene (15.6\%), humulene oxide II (7.9\%), hexahydrofarnesyl acetone $(7.4 \%)$, phytol (7.2\%), humulene oxide I $(4.1 \%), \beta$-elemene $(3.8 \%)$ and 4-terpineol $(3.2 \%)$. The cytotoxic activity against human leukemic (K562), prostatic carcinoma (PC-3) and lung cancer (A549) cell lines of essential oils was assessed using MTT assay. The essential oils of flowers, leaves and stems exhibited significant cytotoxicity against $\mathrm{K}_{562}$ (IC 50 : 12.94-37.89 $\mu \mathrm{g} / \mathrm{mL})$, PC-3 ( $\left.\mathrm{IC}_{50}: 69.06-82.56 \mu \mathrm{g} / \mathrm{mL}\right)$ and $\mathrm{A} 549\left(\mathrm{IC}_{50}: 45.73-66.12 \mu \mathrm{g} / \mathrm{mL}\right)$ cell lines. This is the first report on the chemical constituents and cytotoxic activities of Z. striolatum flowers, leaves and stems essential oils.
\end{abstract}

Keywords: Zingiber striolatum Diels; essential oils; GC-FID/MS; cytotoxic activity. (C) 2019 ACG Publications. All rights reserved.

\section{Plant Source}

The flowers, leaves and stems of Z. striolatum were collected from Guizhou Province of China in September 2018. Identity of the species was confirmed by Prof. Shenghua Wei of Guizhou University of Chinese Medicine. The voucher specimen (NO.1936) was deposited at Guizhou Engineering Center for Innovative Traditional Chinese Medicine and Ethnic Medicine, Guizhou University.

\footnotetext{
*Corresponding author: E- Mail: nlin@gzu.edu.cn (B. Lin); yingzhou71@yeah.net (Y. Zhou)
} 


\section{Previous Studies}

The genus Zingiber, as an important source of essential oil, is widely used as food and traditional medicinal plant [1,2]. Zingiber striolatum Diels, a perennial plant of this genus widely cultivated in China, is a unique healthy vegetable and used as a traditional Chinese medicine for treatment of abdominal pain and diarrhea [3,4]. In previous studies, the ethanol extract of $Z$. striolatum was found to possess nematicidal activity [5] and hypoglycemic activity [6]. It was reported that the major constituents of Z. striolatum rhizome essential oil were $\beta$-phellandrene (23.96\%), sabinene (17.34\%), $\beta$-pinene (11.36\%) and the essential oil demonstrated significant antimicrobial and anticancer properties [7]. To the best of our knowledge, the chemical composition and cytotoxic activities of $Z$. striolatum flowers, leaves and stems essential oils have not been reported.

\section{Present Study}

The dry Z. striolatum flowers, leaves and stems $(800 \mathrm{~g})$ were separately subjected to hydrodistillation for $5 \mathrm{~h}$ using a Clevenger-type apparatus to obtain the essential oils. The flowers, leaves and stems essential oils were separately dried over anhydrous $\mathrm{Na}_{2} \mathrm{SO}_{4}$ and stored in amber bottle at $4^{\circ} \mathrm{C}$ until further analysis.

Table 1. Chemical composition of essential oils from the flowers, leaves and stems of Z. striolatum

\begin{tabular}{|c|c|c|c|c|c|c|}
\hline \multirow{2}{*}{ Compounds $^{\mathrm{a}}$} & \multirow{2}{*}{$\mathbf{R I}^{\mathbf{b}}$} & \multirow{2}{*}{$\mathbf{R I}^{\mathbf{c}}$} & \multicolumn{3}{|c|}{$\%$ Area } & \multirow{2}{*}{ Identification $^{\mathrm{d}}$} \\
\hline & & & flowers & leaves & stems & \\
\hline$\alpha$-Pinene & 933 & $931-939^{\mathrm{a}, \mathrm{b}, \mathrm{c}}$ & 1.7 & 0.2 & - & MS, RI \\
\hline Sabinene & 973 & $954-976^{\mathrm{a}, \mathrm{b}, \mathrm{c},}$ & 0.6 & 0.2 & - & MS, RI \\
\hline$\beta$-Pinene & 977 & $973-980^{\mathrm{a}, \mathrm{b}, \mathrm{c}}$ & 8.2 & 4.3 & 0.2 & MS, RI \\
\hline$\beta$-Myrcene & 992 & $988-991^{\mathrm{a}, \mathrm{b}, \mathrm{c}}$ & 1.1 & 0.1 & - & MS, RI \\
\hline$\alpha$-Phellandrene & 1006 & $1005^{\mathrm{b}, \mathrm{c}}$ & 1.0 & 0.1 & 0.1 & MS, RI \\
\hline$\alpha$-Terpipene & 1017 & $1017-1018^{\mathrm{a}, \mathrm{c}}$ & 0.1 & 0.1 & - & MS, RI \\
\hline p-Cymene & 1025 & $1023-1026^{a, b, c}$ & 1.4 & 0.1 & 0.1 & MS, RI \\
\hline$\beta$-Phellandrene & 1032 & $1031^{\mathrm{c}}$ & 28.5 & 1.2 & 0.5 & MS, RI \\
\hline cis-Ocimene & 1038 & $1038-1040^{\mathrm{b}, \mathrm{c}}$ & 0.2 & - & - & MS, RI \\
\hline trans-Ocimene & 1048 & $1048-1050^{\mathrm{b}, \mathrm{c}, \mathrm{d}}$ & 0.9 & 0.1 & - & MS, RI \\
\hline$\gamma$-Terpinene & 1059 & $1051-1062^{a, b, c}$ & 1.1 & 0.1 & - & MS, RI \\
\hline Tetramethylpyrazine & 1086 & $1089^{c}$ & 0.3 & - & - & MS, RI \\
\hline$\alpha$-Terpinolene & 1088 & $1082-1088^{a, b, c}$ & 0.2 & - & - & MS, RI \\
\hline Linalool & 1102 & $1093-1098^{\mathrm{a}, \mathrm{b}, \mathrm{c}, \mathrm{d}}$ & 1.7 & 0.1 & 0.2 & MS, RI \\
\hline Nonanal & 1104 & $1100-1102^{\mathrm{c}, \mathrm{d}}$ & - & 0.1 & - & MS, RI \\
\hline Fenchol & 1115 & $1113^{c}$ & 0.2 & 0.1 & 0.2 & MS, RI \\
\hline$p$-menth-2-en-1-ol & 1123 & $1126^{\mathrm{c}}$ & 0.5 & 0.1 & 0.1 & MS, RI \\
\hline Nopinone & 1136 & $1137^{\mathrm{c}}$ & 0.1 & 0.2 & 0.2 & MS, RI \\
\hline trans-Pinocarveol & 1139 & $1139^{c}$ & 0.2 & 0.8 & 0.4 & MS, RI \\
\hline trans-Verbenol & 1146 & $1144^{\mathrm{c}}$ & 0.1 & 0.2 & 0.1 & MS, RI \\
\hline Pinocarvone & 1162 & $1162-1164^{b, c}$ & 0.2 & 0.2 & 0.2 & MS, RI \\
\hline Borneol & 1167 & $1165-1167^{b, c}$ & 0.4 & 0.1 & 0.3 & MS, RI \\
\hline Nonanol & 1172 & $1165-1173^{\mathrm{c}, \mathrm{d}}$ & 0.2 & - & 0.2 & MS, RI \\
\hline 4-Terpineol & 1179 & $1169-1177^{\mathrm{a}, \mathrm{b}, \mathrm{c},}$ & 1.3 & 0.7 & 3.2 & MS, RI \\
\hline Cryptone & 1187 & $1184^{\mathrm{c}}$ & 3.3 & 0.4 & 2.7 & MS, RI \\
\hline$\alpha$-Terpineol & 1193 & $1177-1189^{a, b, c}$ & 0.7 & 0.5 & 1.1 & MS, RI \\
\hline Myrtenal & 1196 & $1193^{\mathrm{b}, \mathrm{c}}$ & 0.1 & 0.3 & 0.4 & MS, RI \\
\hline Myrtenol & 1198 & $1994-1213^{\mathrm{b}, \mathrm{c}}$ & 0.5 & 1.7 & 1.3 & MS, RI \\
\hline Sabinol & 1204 & $1143^{c}$ & 0.2 & - & - & MS, RI \\
\hline Decanal & 1206 & $1206^{c}$ & - & - & 0.3 & MS, RI \\
\hline trans-Piperitol & 1209 & $1208^{c}$ & 0.3 & 0.1 & 0.1 & MS, RI \\
\hline trans-Carveol & 1221 & $1217^{\mathrm{c}}$ & 0.1 & 0.2 & 0.3 & MS, RI \\
\hline Cuminic aldehyde & 1241 & $1239^{c}$ & 0.2 & - & 0.1 & MS, RI \\
\hline Carvone & 1244 & $1243^{c}$ & - & - & 0.1 & MS, RI \\
\hline Piperitone & 1254 & $1253^{c}$ & 0.1 & 0.1 & 0.2 & MS, RI \\
\hline 2-Phenylcrotonaldehyde & 1273 & $1274^{\mathrm{c}}$ & 0.1 & 0.1 & - & MS, RI \\
\hline Phellandral & 1275 & $1273^{\mathrm{c}}$ & 1.4 & 0.1 & 0.6 & MS, RI \\
\hline Borneol acetate & 1286 & $1284-1285^{b, c}$ & 0.1 & - & 0.1 & MS, RI \\
\hline
\end{tabular}


Cytotoxic activities of essential oils from Zingiber striolatum Diels

\begin{tabular}{|c|c|c|c|c|c|c|}
\hline Cuminic alcohol & 1293 & $1289^{\mathrm{c}}$ & 0.2 & - & 0.2 & MS, RI \\
\hline 2-Undecanone & 1294 & $1291-1294^{b, c}$ & 0.3 & - & 0.2 & MS, RI \\
\hline 4-Vinyl-2-methoxy-phenol & 1316 & $1317^{\mathrm{c}}$ & - & 0.4 & - & MS, RI \\
\hline Myrtenyl acetate & 1326 & $1327^{\mathrm{c}}$ & 0.1 & 0.4 & 0.2 & MS, RI \\
\hline$\alpha$-Cubebene & 1351 & $1351^{\mathrm{c}}$ & 0.1 & 0.1 & 0.1 & MS, RI \\
\hline$\alpha$-Copaene & 1377 & $1376^{\mathrm{b}, \mathrm{c}}$ & 0.3 & 0.1 & 0.6 & MS, RI \\
\hline$\beta$-Bourbonene & 1386 & $1384^{c}$ & 0.2 & 0.4 & 0.5 & MS, RI \\
\hline$\beta$-Elemene & 1395 & $1391^{\mathrm{b}, \mathrm{c}}$ & 5.5 & 3.0 & 3.8 & MS, RI \\
\hline$\gamma$-Caryophyllene & 1407 & $1404-1415^{\mathrm{b}, \mathrm{c}}$ & - & - & 1.8 & MS, RI \\
\hline$\alpha$-Gurjunene & 1411 & $1409^{c}$ & 0.1 & 0.1 & 0.1 & MS, RI \\
\hline$\beta$-Caryophyllene & 1421 & $1418-1425^{\mathrm{a}, \mathrm{b}, \mathrm{c}}$ & 2.5 & 2.5 & 1.0 & MS, RI \\
\hline$\alpha$-Ionone & 1429 & $1426-1427^{\mathrm{c}, \mathrm{d}}$ & - & 0.5 & - & MS, RI \\
\hline$\gamma$-Elemene & 1435 & $1433^{\mathrm{b}, \mathrm{c}}$ & 0.2 & 0.1 & 2.3 & MS, RI \\
\hline Geranylacetone & 1455 & $1452-1454^{\mathrm{c}, \mathrm{d}}$ & - & 2.5 & - & MS, RI \\
\hline$\alpha$-Humulene & 1458 & $1454^{\mathrm{b}, \mathrm{c}}$ & 14.7 & 12.2 & 15.6 & MS, RI \\
\hline Aromadendrene & 1463 & $1469^{c}$ & - & 0.1 & 0.3 & MS, RI \\
\hline Germacrene D & 1483 & $1456-1481^{\mathrm{a}, \mathrm{b}, \mathrm{c}}$ & 0.1 & - & - & MS, RI \\
\hline$\beta$-Ionone & 1487 & $1485^{\mathrm{c}, \mathrm{d}}$ & - & 0.8 & 0.4 & MS, RI \\
\hline$\beta$-Selinene & 1488 & $1485-1486^{\mathrm{b}, \mathrm{c}}$ & 0.4 & 0.3 & 1.0 & MS, RI \\
\hline 2-Tridecanone & 1497 & $1494-1497^{\mathrm{c}, \mathrm{d}}$ & - & - & 1.1 & MS, RI \\
\hline Bicyclogermacrene & 1497 & $1495-1500^{\mathrm{a}, \mathrm{c}}$ & 0.7 & 0.8 & - & MS, RI \\
\hline Pentadecane & 1501 & $1500^{\mathrm{c}, \mathrm{d}}$ & 1.8 & 0.1 & 0.5 & MS, RI \\
\hline Germacrene A & 1507 & $1504^{c}$ & 0.3 & 0.1 & - & MS, RI \\
\hline$\beta$-Farnesene & 1510 & $1508^{\mathrm{a}, \mathrm{b}, \mathrm{c}}$ & 0.3 & 0.6 & 1.3 & MS, RI \\
\hline$\beta$-Bisabolene & 1510 & $1509^{c}$ & 0.6 & 0.5 & 1.6 & MS, RI \\
\hline$\beta$-Sesquiphellandrene & 1526 & $1524^{\mathrm{c}}$ & 0.4 & - & - & MS, RI \\
\hline Germacrene B & 1559 & $1557^{\mathrm{c}}$ & 0.5 & 0.2 & - & MS, RI \\
\hline Nerolidol & 1566 & $1560-1564^{\mathrm{b}, \mathrm{c}, \mathrm{d}}$ & 0.1 & 2.1 & 1.5 & MS, RI \\
\hline Spathulenol & 1581 & $1572-1576^{\mathrm{c}, \mathrm{d}}$ & 0.8 & 1.9 & 2.8 & MS, RI \\
\hline Caryophyllene oxide & 1585 & $1581^{\mathrm{b}, \mathrm{c}}$ & 0.7 & 2.2 & 2.3 & MS, RI \\
\hline Humulene oxide I & 1597 & $1596^{\mathrm{c}}$ & 0.3 & 0.2 & 4.1 & MS, RI \\
\hline Humulene oxide II & 1615 & $1606^{\mathrm{b}, \mathrm{c}}$ & 3.5 & 6.3 & 7.9 & MS, RI \\
\hline$\alpha$-Bisabolol & 1690 & $1683-1685^{\mathrm{b}, \mathrm{c}}$ & - & 0.1 & 0.4 & MS, RI \\
\hline 2-Pentadecanone & 1700 & $1697-1698^{\mathrm{c}, \mathrm{d}}$ & - & - & 0.5 & MS, RI \\
\hline Pentadecanal & 1715 & $1715^{\mathrm{c}}$ & 0.2 & - & 0.8 & MS, RI \\
\hline Farnesol & 1726 & $1722^{\mathrm{c}}$ & 0.2 & 0.3 & 0.6 & MS, RI \\
\hline Neophytadiene & 1843 & $1837^{\mathrm{c}}$ & - & 0.5 & 0.5 & MS, RI \\
\hline Hexahydrofarnesyl acetone & 1850 & $1844^{\mathrm{c}}$ & 0.2 & 24.7 & 7.4 & MS, RI \\
\hline Farnesyl acetone & 1925 & $1913-1919^{\mathrm{c}, \mathrm{d}}$ & - & 2.1 & 1.0 & MS, RI \\
\hline Methyl palmitate & 1929 & $1926^{\mathrm{c}}$ & 0.2 & 0.1 & 1.5 & MS, RI \\
\hline Sandaracopimaradiene & 1984 & $1968-1975^{\mathrm{c}, \mathrm{d}}$ & - & 3.1 & 2.9 & MS, RI \\
\hline Ethyl palmitate & 1996 & $1993^{c}$ & 0.1 & - & 2.9 & MS, RI \\
\hline Isokaurene & 2015 & $1998^{c}$ & - & 0.2 & - & MS, RI \\
\hline Kaurene & 2065 & $2042-2061^{\mathrm{c}, \mathrm{d}}$ & - & 0.2 & 1.0 & MS, RI \\
\hline Methyl linolelaidate & 2098 & $1980^{c}$ & 0.1 & - & 0.5 & MS, RI \\
\hline Methyl linolenate & 2105 & $2098^{c}$ & 0.1 & - & - & MS, RI \\
\hline Phytol & 2119 & $2114^{c}$ & 0.1 & 11.9 & 7.2 & MS, RI \\
\hline Ethyl linoleate & 2166 & $2160-2162^{\mathrm{c}, \mathrm{d}}$ & 0.1 & 0.2 & 1.5 & MS, RI \\
\hline Ethyl linolenate & 2174 & $2169-2171^{\mathrm{c}, \mathrm{d}}$ & 0.2 & - & 0.2 & MS, RI \\
\hline 1-Tricosene & 2284 & $2278^{c}$ & 0.1 & - & - & MS, RI \\
\hline Tricosane & 2302 & $2300^{\mathrm{c}, \mathrm{d}}$ & 3.2 & 0.2 & 0.3 & MS, RI \\
\hline Squalene & 2841 & $2832^{\mathrm{c}, \mathrm{d}}$ & 0.2 & 0.1 & - & MS, RI \\
\hline \multicolumn{3}{|c|}{ Monoterpene hydrocarbons } & 45.0 & 6.5 & 0.9 & \\
\hline \multicolumn{3}{|l|}{ Oxygenated monoterpenes } & 8.1 & 5.3 & 8.9 & \\
\hline \multicolumn{3}{|l|}{ Sesquiterpene hydrocarbons } & 26.9 & 21.1 & 30.0 & \\
\hline \multicolumn{3}{|l|}{ Oxygenated sesquiterpenes } & 5.6 & 15.2 & 20.6 & \\
\hline \multicolumn{3}{|l|}{ Diterpenes } & 0.3 & 40.6 & 18.1 & \\
\hline \multicolumn{3}{|l|}{ Others } & 11.1 & 6.1 & 15.2 & \\
\hline \multicolumn{3}{|l|}{ Total } & 97.0 & 94.8 & 93.7 & \\
\hline
\end{tabular}

${ }^{\mathrm{a}}$ Compounds are listed in order of their elution from a FB-5MSi column; ${ }^{\mathrm{b}} \mathrm{RI}$ : Retention index on FB-5MSi column, calculated using homologous series of $\mathrm{C}_{9}-\mathrm{C}_{30}$ alkanes; ' ${ }^{2} \mathrm{I}$ : Retention index of literature; a) [8], b) [9], c) NIST 14 and Wiley 275 databases, d) [10]; 'Identification: MS, based on comparison with Wiley 275 and NIST 14 MS databases; RI, based on comparison of calculated RI with those reported in the literature, Wiley 275 and NIST 14 databases; - : not detected. 
The yields of the hydrodistilled flowers, leaves and stems essential oils were $0.39 \%(\mathrm{w} / \mathrm{w})$, $0.27 \%(\mathrm{w} / \mathrm{w})$ and $0.18 \%(\mathrm{w} / \mathrm{w})$ of dry weight, respectively. The essential oils were identified and quantified by GC-FID and GC-MS and the results were presented in Table 1. A total of 73, 68 and 66 compounds representing $97.0 \%, 94.8 \%$ and $93.7 \%$ of the total oil were identified in essential oils of flowers, leaves and stems, respectively. The chemical constituents of the essential oils were classified as monoterpene hydrocarbons (0.9-45.0\%), oxygenated monoterpenes (5.3-8.9\%), sesquiterpene hydrocarbons (21.1-30.0\%), oxygenated sesquiterpenes (5.6-20.6\%), diterpenes (0.3-40.6\%) and others $(6.1-15.2 \%)$. The main constituents of the flowers oil were $\beta$-phellandrene (28.5\%), $\alpha$-humulene $(14.7 \%), \beta$-pinene $(8.2 \%), \beta$-elemene $(5.5 \%)$, humulene oxide II $(3.5 \%)$, cryptone $(3.3 \%)$ and tricosane (3.2\%). The major components of the leaves oil were hexahydrofarnesyl acetone (24.7\%), $\alpha$-humulene $(12.2 \%)$, phytol $(11.9 \%)$, humulene oxide II $(6.3 \%), \beta$-pinene $(4.3 \%)$, sandaracopimaradiene $(3.1 \%)$ and $\beta$-elemene $(3.0 \%)$. The stems oil contained mainly $\alpha$-humulene $(15.6 \%)$, humulene oxide II $(7.9 \%)$, hexahydrofarnesyl acetone (7.4\%), phytol (7.2\%), humulene oxide I $(4.1 \%), \beta$-elemene $(3.8 \%)$ and 4terpineol (3.2\%). In our previous study, the main components of the Z. striolatum rhizomes oil were $\beta$ phellandrene $(23.96 \%)$, sabinene $(17.34 \%), \beta$-pinene $(11.36 \%)$, geranyl linalool $(8.56 \%)$, 4-terpineol (8.27\%), $\alpha$-pipene (5.56\%) and crypton (4.49\%) [7]. These compounds are present in different ratios in other Zingiber species. For example, $\beta$-phellandrene was the main compound of $Z$. spectabilis inflorescence oil, which was a key ingredient of cleaning, cosmetic and medical products [11,12]. $\alpha$ Humulene was found to be the main constituent in Z. zerumbet rhizome essential oil, which was known for its anti-inflammatory property $[13,14]$. Hexahydrofarnesyl acetone and phytol have been reported to be the major constituents in Z. chrysanthum leaf hexane extract, and hexahydrofarnesyl acetone was the oxidation product of phytol $[15,16]$

In the previous studies, essential oils from genus Zingiber have been characterized. The major constituents in the essential oil from $Z$. nimmonii rhizome were $\beta$-caryophyllene $(42.2 \%)$ and $\alpha$ humulene $(27.7 \%)$ [1]. The most abundant constituents in the essential oil from $Z$. officinale rhizome were reported as zingiberene and $a r$-curcumene [1]. Zerumbone was the predominant component in the rhizome oil of $Z$. zerumbet, but the major components of its leaves and flowers oil were $(E)$-nerolidol, $\beta$ caryophyllene and linalool $[9,13]$. The main components of $Z$. cassumunar rhizome essential oil were terpinen-4-ol (40.5\%) and sabinene (17.4\%) [17]. The major components of the essential oil from $Z$. spectabile leaf were $\beta$-caryophyllene (21.3\%) and $\beta$-elemene (12.5\%), the main component in its rhizome oil was zerumbone (59.1\%) [18]. The main constituents of the rhizome oil from $Z$. anamalayanum were $\delta$-2-carene $(52.83 \%)$, camphene (9.83\%), endo-fenchol (9.42\%) [19]. In the present study, the most abundant constituents in Z. striolatum flowers, leaves and stems essential oils were $\beta$-phellandrene (0.5-28.5\%), $\alpha$-humulene (12.2-15.6\%), hexahydrofarnesyl acetone $(0.2-24.7 \%)$ and phytol (0.1-11.9\%). The chemical constituents of $Z$. striolatum essential oils varied according to different parts.

The cytotoxic activities of $Z$. striolatum flowers, leaves and stems essential oils were evaluated against human leukemic (K562), prostatic carcinoma (PC-3) and lung cancer (A549) cell lines using MTT assay. The results were presented in Table 2. The cytotoxic activities of the essential oils were compared with cisplatin as positive control. The essential oils of flowers, leaves and stems exhibited significant cytotoxicity against A549 (IC $\left.{ }_{50}: 45.73-66.12 \mu \mathrm{g} / \mathrm{mL}\right)$, PC-3 $\left(\mathrm{IC}_{50}: 69.06-82.56 \mu \mathrm{g} / \mathrm{mL}\right.$ ) and $\mathrm{K} 562\left(\mathrm{IC}_{50}: 12.94-37.89 \mu \mathrm{g} / \mathrm{mL}\right)$ cell lines in a concentration-dependent manner. The cytotoxic activities of the flowers, leaves and stems essential oils can be attributed to the high content of terpenoids, such as $\alpha$-humulene, $\beta$-pinene, $\beta$-elemene and phytol, which have been reported to have cytotoxic activity [20-23]. In addition, $\beta$-caryophyllene, as a chemical component with less content in $Z$. striolatum essential oils, significantly potentiated the cytotoxic activity of $\alpha$-humulene against human breast adenocarcinoma cell line (MCF-7) [24]. Therefore, the cytotoxic activities of Z. striolatum flowers, leaves and stems essential oils may be attributed to the specific chemical constituents, and/or synergies between various components.

Z. zerumbet rhizome oil exhibited significant cytotoxicity towards human cancer cell lines (A549, MDAMB-231, A431, K562, WRL-68, and HaCaT) with $\mathrm{IC}_{50}$ values $(33.37-46.02 \mu \mathrm{g} / \mathrm{mL}$ ) [13]. Z. officinale essential oil was found strong cytotoxic activity against human cancer cell lines (HO-8910 
and Bel-7402) and $\mathrm{IC}_{50}$ values were 0.00643 and $0.00256 \%$ (v/v), respectively [25]. In the present study, the essential oils of $Z$. striolatum flowers, leaves and stems exhibited significant cytotoxicity

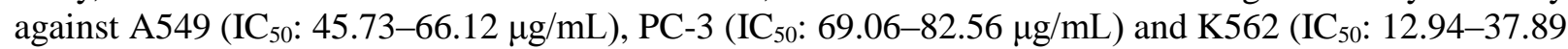
$\mu \mathrm{g} / \mathrm{mL}$ ) cell lines. The cytotoxic activity of the essential oils against $\mathrm{K} 562$ cell line was found significantly higher than that against PC-3 and A549 cell lines ( $\mathrm{p}<0.05)$.

Table 2. Cytotoxic activity of essential oils from the flowers, leaves and stems of $Z$. striolatum

\begin{tabular}{cccc}
\hline \multirow{2}{*}{ Treatment } & \multicolumn{3}{c}{ Cell line $\left(\mathbf{I C}_{\mathbf{5 0} \mathbf{\mu g} / \mathbf{m L})^{\mathbf{a}}}\right.$} \\
\cline { 2 - 4 } & K562 $^{\mathbf{b}}$ & $\mathbf{P C}^{\mathbf{c}}$ & $\mathbf{A 5 4 9}^{\mathbf{d}}$ \\
\hline Flowers & $26.75 \pm 1.28$ & $82.56 \pm 2.83$ & $52.65 \pm 1.82$ \\
Leaves & $37.89 \pm 1.67$ & $77.20 \pm 1.87$ & $45.73 \pm 1.56$ \\
Stems & $12.94 \pm 1.38$ & $69.06 \pm 2.31$ & $66.12 \pm 2.34$ \\
Cisplatin & $3.42 \pm 0.28$ & $10.26 \pm 0.64$ & $7.98 \pm 0.23$ \\
\hline
\end{tabular}

${ }^{\mathrm{a}} \mathrm{I}_{50}$ : The concentration of compound that affords a $50 \%$ reduction in cell growth (after $48 \mathrm{~h}$ of incubation); ${ }^{b} H u m a n$ leukemic cell line; ${ }^{\mathrm{c}}$ Human prostatic carcinoma cell line; ${ }^{\mathrm{d}} \mathrm{Human}$ lung cancer cell line.

\section{Acknowledgments}

The authors are grateful for the financial support grant from National Key R\&D Program of China (2018YFC1708100); Guizhou Science and Technology Program [Qian Ke He Zhi Cheng (2017) 2850, Qian Ke He Ping Tai Ren Cai (2018) 5781-49 and Qian Ke He Ji Chu (2019) 1402].

\section{Supporting Information}

Supporting Information accompanies this paper on http://www.acgpubs.org/journal/records-ofnatural-products

\section{ORCID}

Minyi Tian: 0000-0003-1047-7964

Yi Hong: 0000-0002-6574-8373

Xianghuan Wu: 0000-0003-0400-989X

Min Zhang: 0000-0002-6195-7637

Bing Lin: 0000-0002-0725-5554

Ying Zhou: 0000-0002-2319-7024

\section{References}

[1] B. Sabulal, M. Dan, A. J. J, R. Kurup, N. S. Pradeep, R. K. Valsamma and V. George (2006). Caryophyllene-rich rhizome oil of Zingiber nimmonii from South India: Chemical characterization and antimicrobial activity, Phytochemistry 67, 2469-2473.

[2] J. W. Tan, D. A. Israf and C. L. Tham (2018). Major bioactive compounds in essential oils extracted from the rhizomes of Zingiber zerumbet (L) Smith: A mini-review on the anti-allergic and immunomodulatory properties, Front. Pharmacol. 9, 652.

[3] K. P. Deng, R. J. Deng, J. X. Fan and E. F. Chen (2018). Transcriptome analysis and development of simple sequence repeat (SSR) markers in Zingiber striolatum Diels, Physiol. Mol. Biol. Plants 24(1), 125-134.

[4] B. Liu, M. Yang, D. G. Yang, H. B. Chen and H. M. Li (2018). Zingiber striolatum diels derived O/N dual-doped porous carbon for high performance oxygen reduction reaction and energy storage, Int. J. Hydrogen Energy 43, 18270-18278.

[5] L. J. Hong, G. H. Li, W. Zhou, X. B. Wang and K. Q. Zhang (2007). Screening and isolation of a nematicidal sesquiterpene from Magnolia grandiflora L, Pest Manag. Sci. 63, 301-305.

[6] T. H. Chen, J. Y. Cai, J. Ni and F. Yang (2016). An UPLC-MS/MS application to investigate chemical compositions in the ethanol extract with hypoglycemic activity from Zingiber striolatum Diels, J. Chin. Pharm. Sci. 25(2), 116-121. 
[7] M. Y. Tian, T. T. Liu, X. H. Wu, Y. Hong, X. L. Liu, B. Lin and Y. Zhou (2019). Chemical composition, antioxidant, antimicrobial and anticancer activities of the essential oil from the rhizomes of Zingiber striolatum Diels, Nat. Prod. Res. https://doi.org/10.1080/14786419.2018.1544979.

[8] T. Üstüner, S. Kordali and A. U. Bozhüyük (2018). Herbicidal and fungicidal effects of Cuminum cyminum, Mentha longifolia and Allium sativum essential oils on some weeds and fungi, Rec. Nat. Prod. 12(6), 619-629.

[9] J. Chane-Ming, R. Vera and J. -C. Chalchat (2003). Chemical composition of the essential oil from rhizomes, leaves and flowers of Zingiber zerumbet Smith from Reunion Island, J. Essent. Oil Res. 15, 202-205.

[10] P. Evangelia, V. Constantinos, C. Maria and T. Olga (2017). Study of volatile components of Acacia farnesiana Willd. flowers, Rec. Nat. Prod. 11(5), 474-478

[11] M. G. B. Zoghbi and E. H. A. Andrade (2005). Volatiles of the Etlingera elatior (Jack) R. M. Sm. and Zingiber spectabile Griff.: Two Zingiberaceae cultivated in the Amazon, J. Essent. Oil Res. 17, 209-211.

[12] C. Formighieri and A. Melis (2014). Carbon partitioning to the terpenoid biosynthetic pathway enables heterologous $\beta$-phellandrene production in Escherichia coli cultures, Arch. Microbiol. 196, 853-861.

[13] R. C. Padalia, R. S. Verma, A. Chauhan, V. R. Singh, P. Goswami, S. Singh, S. K. Verma, S. Luqman, C. S. Chanotiya and M. P. Darokar (2018). Zingiber zerumbet (L.) Roscoe ex Sm. from northern India: Potential source of zerumbone rich essential oil for antiproliferative and antibacterial applications, Ind. Crops Prod. 112, 749-754.

[14] A. P. Rogerio, E. L. Andrade, D. F. P. Leite, C. P. Figueiredo and J. B. Calixto (2009). Preventive and therapeutic anti-inflammatory properties of the sesquiterpene $\alpha$-humulene in experimental airways allergic inflammation, Brit. J. Pharmacol. 158, 1074-1087.

[15] D. Chandra, P. Chaubey, A. Parki, O. Prakash, R. Kumar and A. K. Pant (2017). Study on chemical diversity among plant parts of Zingiber chrysanthum and their antioxidant assay, J. Biologic. Active Prod. Nature 7(2), 107-117.

[16] H. -J. Bestmann, B. Classen, U. Kobold, O. Vostrowsky, F. Klingauf and U. Stein (1988). Steam volatile constituents from leaves of Rhus typhina, Phytochemistry 27(1), 85-90.

[17] W. Chaiyana, S. Anuchapreeda, P. Leelapornpisid, R. Phongpradist, H. Viernstein and M. Mueller (2017). Development of microemulsion delivery system of essential oil from Zingiber cassumunar Roxb. rhizome for improvement of stability and anti-inflammatory activity, AAPS PharmSciTech 18(4), 13321342.

[18] Y. Sivasothy, K. Awang, H. Ibrahim, K. L. Thong, N. Fitrah, X. P. Koh and L. K. Tan (2012). Chemical composition and antibacterial activities of essential oils from Zingiber spectabile Griff, J. Essent. Oil Res. 24(3), 305-301.

[19] M. Salim, T. K. A. Kabeer, S. A. Nair, M. Dan, M. Sabu and S. Baby (2016). Chemical profile, antiproliferative and antioxidant activities of rhizome oil of Zingiber anamalayanum from Western Ghats in India, Nat. Prod. Res. 30(17), 1965-1968.

[20] J. Legault, W. Dahl, E. Debiton, A. Pichette and J. -C. Madelmont (2003). Antitumor activity of balsam fir oil: production of reactive oxygen species induced by $\alpha$-humulene as possible mechanism of action, Planta Med. 69, 402-407.

[21] W. Wang, N. Li, M. Luo, Y. G. Zu and T. Efferth (2012). Antibacterial activity and anticancer activity of Rosmarinus officinalis L. essential oil compared to that of its main components, Molecules 17, 2704-2713.

[22] B. T. Zhai, N. N. Zhang, X. M. Han, Q. J. Li, M. M. Zhang, X. Y. Chen, G. H. Li, R. N. Zhang, P. Chen, W. G. Wang, C. X. Li, Y. Xiang, S. P. Liu, T. Duan, J. S. Lou, T. Xie and X. B. Sui (2019). Molecular targets of $\beta$-elemene, a herbal extract used in traditional Chinese medicine, and its potential role in cancer therapy: A review, Biomed. Pharmacother. 114, 108812.

[23] L. Sheeja, D. Lakshmi, S. Bharadwaj and K. S. Parveen (2016). Anticancer activity of phytol purified from Gracilaria edulis against human breast cancer cell line (MCF-7). Int. J. Curr. Sci. 19(4), E 36-46.

[24] J. Legault and A. Pichette (2007). Potentiating effect of $\beta$-caryophyllene on anticancer activity of $\alpha$ humulene, isocaryophyllene and paclitaxel, J. Pharm. Pharmacol. 59, 1643-1647.

[25] W. Wang, L. Zhang, N. Li and Y. G Zu (2012). Chemical composition and in vitro antioxidant, cytotoxicity activities of Zingiber officinale Roscoe essential oil, Afr. J. Biochem. Res. 6(6), 75-80.

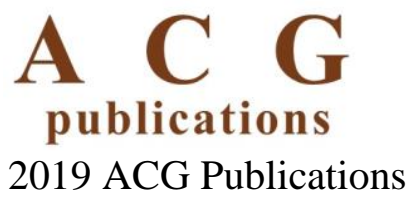

